\title{
ON A PELAGIC PENAEID PRAWN, FUNCHALIA WOODWARDI JOHNSON, NEW TO THE BRITISH FAUNA
}

\author{
By Isabella Gordon, D.Sc. and R. W. Ingle \\ British Museum (Natural History), London
}

(Text-fig. I)

On 30 July 1955 Dr J. H. Fraser, of the Scottish Home Department, Marine Laboratory, Aberdeen, sent to the British Museum for determination two adult females of a penaeid prawn collected at or.56-02.0 h B.S.T. near the surface ( $15 \mathrm{fm}$.) at Rosemary Knoll, to the north-west of the Outer Hebrides, on 22 July 1955 . The actual depth at this locality, $59^{\circ} \mathrm{I2} 2^{\prime} \mathrm{N} ., 10^{\circ} \mathrm{og} 9^{\prime} \mathrm{W}$., is $229 \mathrm{fm}$ (4I9 m). These specimens were identified by one of us (R. W. I.) as Funchalia woodwardi Johnson. Later the senior author confirmed this determination and wrote to Dr Fraser as follows:

This is the first British record of the genus Funchalia...For some reason not understood adult specimens of Funchalia are rarely captured, unless by fish.... In 1936 Burkenroad showed that two species had been confused under Funchalia (Funchalia) woodwardi Johnson and in 1940 he added two new species in the Dana collection, one from the Indian Ocean, the other from the Canaries. The older references do not, therefore, necessarily refer to woodwardi. Authentic adult specimens of $F$. woodwardi are known from Madeira (holotype, + in B.M.); off South Africa (Calman, 1925, 3 우, 2 in B.M.; Barnard, 1950, 16 ơ oิ, 6 웅, all from stomachs of stock-fish, Merluccius); and off Nice in the S. of France (2 $9+9$ in Villefranche-sur-mer Colln. Roger, 1938).

She also asked to see the third specimen, which proved to be an adult male.

Dr Fraser's reply was interesting:

I had no idea, when we caught them [Funchalia], that they would turn out to be anything so unusual. We only retained three, out of a total of 84 in a half-hour haul, thinking a quick glance through the literature at Aberdeen would tell us that they were something common enough. (I must confess the remainder of the catch went to prove their comestible value!) Indeed it seems as though they are common enough, given the right type of gear to catch them and used in the right place. Our programme in July was specifically arranged to look into the identification of traces made on the echo sounder and these prawns were the cause of one of them.... The gear was an Icelandic Pelagic Trawl specially fitted with a small mesh cod-end (the net designed for catching herring), and I expect we are the first to use such a net near the surface over these oceanic banks.

I do not know yet for certain if they are subject to diurnal migration, but I strongly suspect they are distributed in the deeper layers during the day, where they are caught by the deeper living fish, such as Merluccius, and swarm at the surface at night as we found them. [Letter to I. G. dated I7 November 1955.] 
Later in September Dr Fraser sent a photo copy of the appropriate part of the echo trace.

It starts at $00.40 \mathrm{~h}$ on $2 \mathrm{r} / \mathrm{vii} / 55$ with a distinct double trace, at $\mathrm{I} 5-20 \mathrm{fm}$. and at 35-40 fm. approximately, and we chose to sample the lower one first. This gave a haul of small fish only-Gadus poutassou and scopelids, mostly Myctophum glaciale. By the time we had completed the first haul the two traces had merged-at about midnight (or.40 h B.S.T. at that longitude)-and our second haul thus sampled the mixture. This caught similar numbers of G. poutassou and scopelids, and in addition 84 Funchalia, so that it seems justifiable to infer that the upper trace prior to midnight was Funchalia. This was first seen to appear as a scattered trace at about $23.00 \mathrm{~h}$ the previous evening, i.e. about $2 \frac{1}{2} \mathrm{~h}$ before midnight, either because we steamed into the shoal at that time, or because the prawns had started shoaling in the upper layers.

The colour, in life, of the specimens was a pleasant yellowish-orange with a very bright scarlet area (still to be seen in the preserved specimen, though not so brilliantly) on the back of the cephalothorax. [Letter to I. G. dated 26 November I955.]

\section{Funchalia Johnson}

For references and synonymy see Burkenroad, I936, p. I26; Barnard, I950, p. 608.

At present the genus Funchalia comprises five species, namely $F$. woodwardi Johnson, I867, F. villosa (Bouvier, 1905), $F$. danae Burkenroad, I940, $F$. taaningi Burkenroad, I940, and F. balboae (Faxon, I893). Burkenroad (1934, pp. 76-7, and 1936, p. 136) thought it necessary to establish a new subgenus Pelagopenaeus for the last-named species, which differs in several minor details from the first two species. But this difference breaks down, at least in part, since the thelycum of his species Funchalia danae resembles that of Pelagopenaeus, and as moreover there are so few species in the genus, it seems to us that subgenera are unnecessary.

For many years all specimens of Funchalia, whether adult or immature, were referred to $F$. woodwardi, but, as stated in the letter to Dr Fraser, Burkenroad (1936, pp. I28-35) found that two species had been confused under that name. Roger (1938, p. 25) arrived independently at the same conclusion, for he writes: 'Il semble bien que le genre Funchalia d'après les auteurs présente au moins deux espèces différentes actuellement connues. Funchalia vanhöffeni, que Lenz et Strunck ont décrit, différait assez notablement de Funchalia woodwardi Johnson'. Roger was apparently unaware of Burkenroad's paper when he described the two females of $F$. woodwardi in the Villefranche-sur-mer collection. Burkenroad used Bouvier's name Hemipenaeopsis villosus, later retracted in favour of Funchalia woodwardi, for this second species. Roger's record of $F$. woodwardi from the Mediterranean would seem to confirm Burkenroad's suggestion that larvae referred to Aristeus antennatus by Monticelli and Lo Bianco (I902) and to Aristeomorpha foliacea by Stephensen (I923) are probably referable to Funchalia woodwardi. Where no information has been given as to the number of rostral spines and other characters, or where the material is immature, it is probable that either 


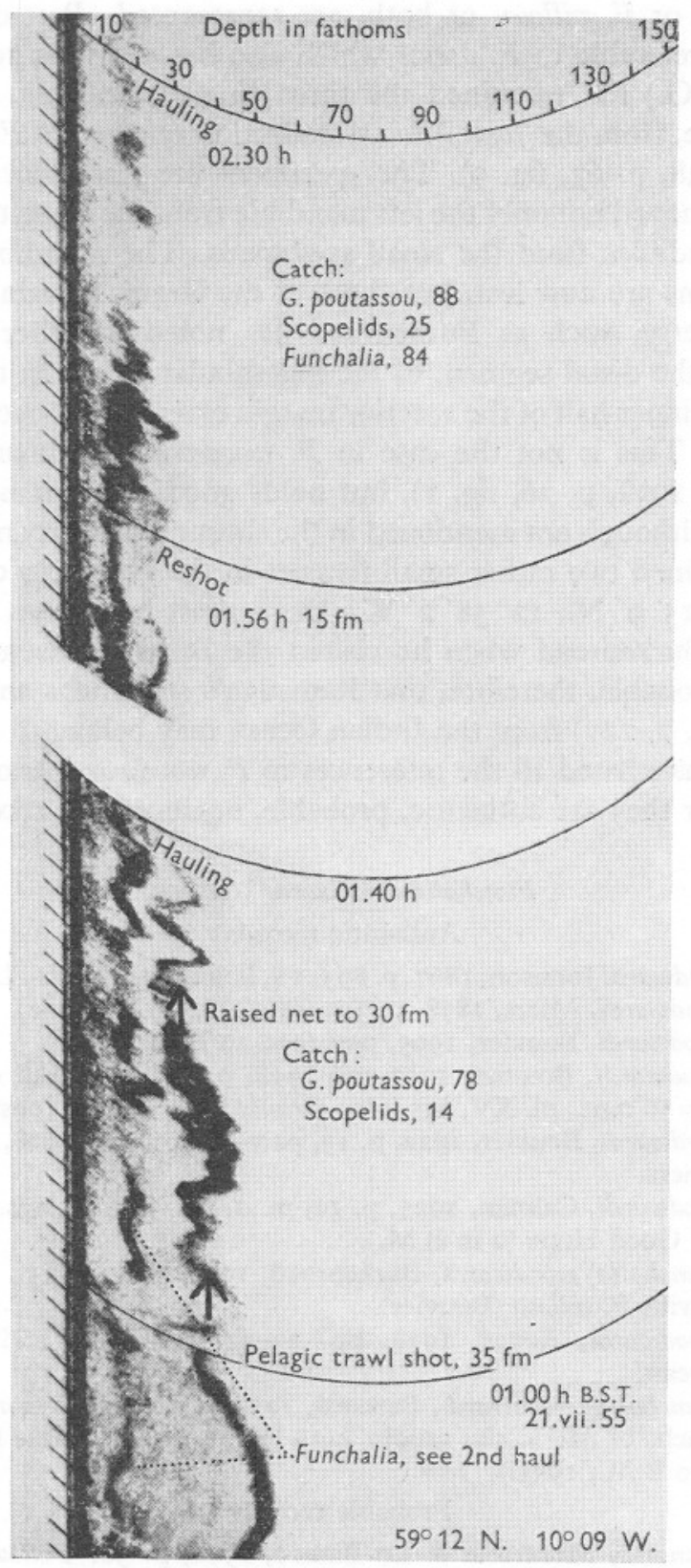

Fig. I. Echo trace prepared by Dr Fraser. The actual depth is $229 \mathrm{fm}$ and the bottom does not therefore appear on this trace, phased at $0-160 \mathrm{fm}$. The time scale on left-hand edge is in 2 min ticks. The time at the start and finish of each of the two hauls is given in B.S.T. and the natural midnight at $10^{\circ} \mathrm{W}$. is at or.40 hr. The first catch comprised 78 Gadus poutassou and I4 scopelids; the second $88 \mathrm{G}$. poutassou, 25 scopelids and 84 Funchalia woodwardi Johnson. 
$F$. woodwardi, or $F$. villosa, or both, are represented. Part of the material may even be referable to $F$. danae which also has a similar rostral formula. One of us (I.G.) has examined the three small specimens, the largest an immature male, from the fohn Murray collection referred to $F$. woodwardi by Ramadan (1938, p. 63, fig. 9). The specimens are imperfect and Ramadan apparently removed not only the left mandible from the largest specimen, but also both mandibles from the small specimens. The mandibles of the two small specimens are now lost, but those of the largest remain. They show a slight asymmetry, such as Burkenroad has noted in other specimens of Funchalia, in the distal segment of the mandibular palp. In the left mandibular palp the inner half of the anterior margin extends far beyond the shallow emargination. This is not the case in F. woodwardi (Calman, 1925, pl. 3, fig. 7; Roger, I938, p. 26, fig. I), but holds good for $F$. danae Burkenroad (I940, p. 36), although not mentioned in the short preliminary note. However, we have examined two rather small females in the Discovery collection from St. I 594, $04^{\circ} 15^{\prime} 9^{\prime \prime} \mathrm{N}$., $12^{\circ} 58^{\prime} 2^{\prime \prime} \mathrm{W}$.; these must have been determined as $F$. danae by Burkenroad when he visited the British Museum in 1938-39. It is highly probable, therefore, that Ramadan's specimens and perhaps that of Balss (I925, p. 227) from the Indian Ocean may belong to $F$. danae.

Below we have listed all the references to $F$. woodwardi known to us indicating whether they are authentic, probable, or uncertain, records.

\section{Funchalia woodwardi Johnson \\ Authentic records}

Funchalia woodwardi Johnson, I867, p. 895. I + , holotype in B.M. Locality Madeira.

Funchalia woodwardi, Miers, I878, p. 309 (reference to holotype).

Funchalia woodwardi, Bouvier, I905, part (acc. to Burkenroad).

Funchalia woodwardi, Bouvier, 1907 and 1908, p. 93, part. For example ${ }^{\star}$ from St. I856, $l=56 \mathrm{~mm}$., pl. XV, figs. I-2; Grimaldiella richardi (post-larval) in part.

Funchalia woodwardi, Bouvier, I922, p. 13 , part- ${ }^{-1}$ from St. $3028, l=100 \mathrm{~mm}$. and perhaps others.

Funchalia woodwardi, Calman, I925, p. Io, pl. 2, fig. 5, pl. 3, figs. 6-8. 3 우 from off Cape of Good Hope (2 in B.M.).

Funchalia (Funchalia) woodwardi, Burkenroad, 1936, pp. 129-35. No new records; compared with $F$. villosa (Bouvier).

Funchalia woodwardi, Roger, 1938, pp. 23-32, figs. I-4. 2 우 from Western Mediterranean.

Funchalia (Funchalia) woodwardi, Barnard, I950, p. 609, fig. II2a-h. I6 ồ, 69 , from stomachs of Merluccius caught Jan.-Feb. 1943, off Table Bay. (3우, 6 o o presented to B.M., 1955.)

Probable records

Aristeus antennatus, Monticelli \& Lo Bianco, 1902, p. 30. Probable larvae of $F$. woodwardi acc. Burkenroad, 1936, p. I35.

Aristeomorpha foliacea, Stephensen, 1923, p. I5, fig. 6. Probable larvae of F. woodwardi acc. Burkenroad, I936, p. I35.

? Larva of Funchalia woodwardi, Stephensen, 1923, p. 26, fig. Io. 
(a) Atlantic Ocean

\section{Uncertain records}

Funchalia woodwardi, Murray \& Hjort, I9I2, p. 668 in Table.

Funchalia woodwardi, Sund, I920, p. 32, 67 immature specimens-the majority from night hauls and 45 from between 50 and $150 \mathrm{~m}$ depth.

Funchalia woodwardi, Stephensen, I923, p. I7. 17 specimens-small $\hat{o} 0 \hat{~ a n d ~}+90$ from 45 to $70 \mathrm{~mm}$ in length, but no details given; the rest young. ( 8 in 8 hauls at 7 stations in Mediterranean and 9 in 4 hauls at 3 stations in Atlantic.)

Funchalia sp., Lenz \& Strunck, I9I4, p. 307, fig. $3 a$ and $b$. One immature specimen, off St Helena. The number of rostral teeth suggests either $F$. woodwardi or F. danae.

\section{(b) Indian Ocean}

Funchalia woodwardi, Balss, I9I4, p. 593; 1925, p. 227. I $\circ$ about $50 \mathrm{~mm}$ long at $16^{\circ} 8^{\prime}$ S., $97^{\circ} \mathrm{I} 4^{\prime} \mathrm{E}$.

Funchalia (Funchalia) woodwardi, Ramadan, 1938, p. 63, fig. 9. Three young, the largest an immature ${ }^{*}$. Perhaps referable to $F$. danae Burkenroad (I.G.).

\section{REMARKS}

Between I 867 and 1938 adult specimens of Funchalia woodwardi were captured sporadically in very small numbers ( $\mathrm{I}$ to 3 ) at various localities in the eastern Atlantic, from the Cape region to approximately $40^{\circ} \mathrm{N}$., and in the western Mediterranean. Good descriptions of the female have been given by Calman (1925) and by Roger (1938). For the first time a considerable number of adults were obtained in January-February 1943 from the stomachs of Merluccius by Mr Rattray of the Low Temperature Laboratories, Cape Town, while he was studying the food and diseases of the stock-fish. Although many of the specimens were mutilated, Barnard was able to describe and figure for the first time the petasma and appendix masculina of the adult male (Barnard, I950, p. 609, fig. II $2 e$ and $f$ ). The petasma is asymmetrical, either the left or the right half being the longer.

The haul mentioned by Dr Fraser in the letters quoted above (see p. 475) is of special interest because for the first time free-swimming adults were obtained in quantity -84 in a half-hour haul. The three specimens selected at random as a sample for determination are a male and two females measuring from $\mathrm{I} 20$ to $\mathrm{I} 30 \mathrm{~mm}$ in length, neither female being impregnated. The catch, therefore, apparently consisted of adults of both sexes. Moreover, this is the first British record and by far the most northerly locality for the species. The depth at which the adults were swarming, as indicated by the upper trace on the echo sounder, was approximately I5-20 fm or less than $40 \mathrm{~m}$.

Little is known of the bathymetric range, habits or development of Funchalia. Bouvier regarded the genus as bathypelagic, though capable of ascending to the upper layers; 'from the catches of the Michael Sars it would appear that the young at least are denizens of the upper water layers though not of the 
very surface' (Sund, I920, p. 32). Most of the Michael Sars specimens were collected in night hauls at 50-150 m, but of the seven taken in day hauls four were also from 50 and $100 \mathrm{~m}$ (Murray \& Hjort, I9I2, table on p. 668)*. Burkenroad says that Funchalia is a pelagic genus with autogenous statolith in the statocyst chamber which, however, retains an opening to the exterior (I936, p. I28). Sund regarded all his material as immature, although the largest specimen measured $75 \mathrm{~mm}$ in length; Bouvier and Stephensen sexed their specimens of about $45-70 \mathrm{~mm}$ but the majority of these, if not all, were probably not fully adult. The maximum recorded length is approximately I57 mm (holotype, rostrum damaged). It is quite likely that $F$. woodwardi may exhibit vertical diurnal migrations of considerable magnitude such as have been described for Gennadas and other deep-water Crustacea Malacostraca (Waterman et al., 1939).

The British Museum authorities are indebted to the Director of the South African Museum for nine specimens obtained from stomachs of Merluccius and to the Director of the Scottish Home Department, Marine Laboratory, Aberdeen, for permission to retain the male and one female from Rosemary Knoll.

\section{REFERENCES}

BaLss, H., I9I4. Diagnosen neuer Macruren der Valdiviaexpedition. Zool. Anz., Bd. 44 , pp. 592-9.

- 1925. Macrura der Deutschen Tiefsee-Expedition. 2. Natantia, Tiel A. Wiss. Ergebn. 'Valdivia', Bd. 20, (5), pp. 217-315.

BARNARD, K. H., I950. Descriptive catalogue of South African decapod crustacea (crabs and shrimps). Ann. S. Afr. Mus., Vol. 38, 837 pp.

Bouvier, E. L., I905. Sur les Pénéides et les Sténopides recueillis dans l'Atlantique oriental. C.R. Acad. Sci., Paris, T. I40, pp. 980-3.

- 1907. Sur la position zoologique, les affinités et le développement des Pénéides du genre Funchalia Johnson. C.R. Acad. Sci. Paris, T. I44, pp. 95I-4.

— 1908. Crustacés Décapodes (Pénéides). Résult. Camp. sci. Monaco, Fasc. 33, I22 pp.

- I 1922. Observations complémentaires sur les Crustacés Décapodes. Résult. Camp. sci. Monaco, Fasc. 62, 106 pp.

BURKENROAD, M. D., I934. The Penaeidea of Louisiana with a discussion of their world relationships. Bull. Amer. Mus. nat. Hist., Vol. 68, pp. 6I-I43.

- 1936. The Aristaeinae, Solenocerinae and pelagic Penaeinae. Bull. Bingham oceanogr. Coll., Vol. 5, No. 2, I5I pp., 7 I text-figs.

- 1940. Preliminary descriptions of twenty-one new species of pelagic Penaeinae (Crustacea Decapoda) from the Danish Oceanographical Expeditions. Ann. Mag. nat. Hist., Ser. II, vol. 6, pp. 35-54.

Calman, W. T., I925. On macrurous decapod Crustacea collected in South African waters by the S.S. Pickle. Rep. Fish. mar. Biol. Survey Cape Town, Vol. 4 (3), 26 pp., 4 pls.

FAxON, W., I893. Reports on the Dredging Operations . . . . . by the 'Albatross'. VI. Preliminary descriptions of new species of Crustacea. Bull. Mus. comp. Zool. Harv., Vol. 24, pp. I49-220.

* This work lists sixty-two specimens, but the total given in Sund, 1920, p. 32, is sixty-seven. 
Johnson, J. Y., I867. Description of a new genus and new species of Macrurous Decapod Crustaceans..., discovered at Madeira. Proc. zool. Soc. Lond., I867, pp. 895-90r.

Lenz, H. \& StRunCK, K., I9I4. Die Dekapoden der Deutschen Südpolar Expedition I90I-03. I. Brachyuren und Macruren ... Dtsch. SüdpolExped., Bd. I5 (Zool. 7), Hft. 3 (6), pp. $257-345$, figs. I-5, pls. xii-xxii.

Miers, E. J., I878. Notes on the Penaeidae in the collection of the British Museum.... Proc. Zool. Soc. Lond., I878, pp. 298-310, pl. xvii.

Monticelli, Fr. Sav. \& Lo BiAnco, S., I902. Su la probabile larva di Aristeus antennatus Risso. Monit. zool. ital., Vol. 13, Suppl., pp. 30-I.

Murray, J. \& HJort, J., I9I2. The Depths of the Ocean. 82I pp. London: Macmillan.

Ramadan, M. M., 1938. Crustacea: Penaeidae. Sci. Rep. Murray Exped., Vol. 5, No. 3, pp. 35-76.

Roger, E. J., I938. Quelques observations au sujet d'un Crustacé Décapode Macroure assez rare: Funchalia woodwardi Johnson. Bull. Soc. zool. Fr. T. 63, pp. 23-32.

Stephensen, K. H., I923. Decapoda Macrura (excl. Sergestidae). Rep. Danish oceanogr. Exped. Medit., Bd. II (D 3), 85 pp.

Sund, O., I920 (reissued I932). Peneides and Stenopides from the Michael Sars North Atlantic Exp. I9I0. Rep. Sars. N. Atl. Deep Sea Exped., Bd. II (2), 36 pp.

Waterman, T. H., NunNemacher, R. F., Chace, F. A., Jr. \& Clarke, G. L., I 939. Diurnal vertical migrations of deep-water plankton. Biol. Bull., Woods Hole, Vol. 76, pp. 254-79. 